\title{
EFFECT OF CHITOSAN AND SALICYLIC ACID AS EXOGENOUS ELICITORS ON GROWTH AND BIOCHEMICAL CONSTITUENTS OF BROCCOLI SEED SPROUTS
}

\author{
Rasha M. Bondok ${ }^{1^{*}}$, Abou El-Yazied ${ }^{2}$ A., Abd El-Gawad ${ }^{2}$ H.G. and \\ Zeinab M. Abd El-Ghany ${ }^{1}$
}

1- Regional Center for Food and Feed, Agric. Res. Center. Giza, Egypt

2- Horticulture Dept., Fac. of Agric., Ain Shams Univ., P.O. Box 68, Hadayek Shoubra 11241, Cairo, Egypt

*Corresponding author: rashabondok@agr.asu.edu.eg

\section{ABSTRACT}

The effect of chitosan and salicylic acid treatments to investigate the seedling growth parameters of Broccoli seed sprouts (Tiburon f1) cultivar was the aim of this study. Salicylic Acid and Chitosan are the (elicitors) that stimulate the sprout, which are divided into Biotic (biological origin), abiotic (chemical or physical origin) elicitors and phytohormones have been applied alone or in combinations, in hydroponic solutions or sprays, and in different selected time points of the sprout growth or during post-harvest. Cumulative time had been completed (harvest time) using tap water, chitosan at 25, 50,100 ppm and salicylic acid at $65,130,260 \mathrm{ppm}$ for seed soaking and sprouting , then precooled and air-dried sprouts were randomly chosen from glass jar (replicate) to collect data of sprout length, hypocotyl length, radical length, dry weight and fresh weight. Also, Samples of harvested 3,5 and 7 days old etiolated broccoli dried using air draft oven at $65.5 \mathrm{C}^{\circ}$ then grounded into powder for chemical analysis while fresh sprouts and seeds were analyzed for total phenols. However treatment with chitosan at $100 \mathrm{ppm}$ cleared that the moisture, protein, ash, fiber, calcium, potassium, and total phenols of sprouts were increased by $9.63 \%, 33.73 \%, 11.80,11.67 \%, 336.50$ ppm, $196.43 \mathrm{ppm}$ and $66.51 \mathrm{mg} / 100 \mathrm{~g}$, respectively. Treated sprouts with salicylic acid at $65 \mathrm{ppm}$ concentrate were also induced an increments on the same constituents reached $9.53 \%, 33.40 \%, 11.63$, $10.46 \%, 333.50 \mathrm{ppm}, 190.60 \mathrm{ppm}$ and $62.90 \mathrm{mg} /$ $100 \mathrm{~g}$, respectively over control (untreated). Therefore, treated sprouts with chitosan or salicylic acid
\end{abstract}

could be considered as useful tool for improving the growth characters and bioactive metabolites of Broccoli seed sprouts for their Production of anticancer materials. As well secondary metabolic pathways respond to specific treatments with elicitors would be the basis for to enhance the production of secondary metabolites, in order to produce quality and healthy fresh foods.

Keywords: Elicitor, Sprout seeds, Broccoli, Chitosan, Salicylic acid, Phenolic compounds and chemical composition

\section{INTRODUCTION}

Broccoli seed sprouts are a surprisingly powerful little food with thoroughly researched a good health benefits. Most notably, they have been shown to significantly impact several types of broccoli sprouts may have the more high quantity of vitamins and minerals as $\mathrm{K}$ and $\mathrm{Ca}$ found in adult broccoli, and they contain a great deal more total phenols (Jinjun et al 2014). Broccoli seed sprouts are recognised as wellness and health-promoting foods due to its high content of nutrients and bioactive compounds that includes vitamins, flavonoids, hydroxycinnamic acids and glucosinolates (Jeffery and Araya, 2009). These phytochemicals seem to play against the development of different types of cancer and cardiovascular diseases (Hooper and Cassidy, 2006 and Li, Zhang et al 2010).

Chitosan is a linear polysaccharide composed of randomly distributed $\beta$ - $(1 \rightarrow 4)$-linked $N$-acetyl-D glucosamine and $D$-glucosamine. It was made by 
treating the chitin shells of shrimp and other crustaceans with an alkaline substance, like sodium hydroxides (Bautista-Banos et al 2006). In addition, recent studies have revealed that chitosan enhances the yield and quality of broccoli seed sprouts and exhibit elicitor activity in broccoli seed sprouts (No et al 2003 and Pérez-Balibrea et al 2011). Chitosan stimulated the growth and yield of broccoli seed sprouts, which reported by (No et al 2003 and Lee et al 2005). Chitosan has a great number of commercial and possible biomedical activities. However agriculture used as a seed treatments and bio pesticide helping plants to fight off fungal infections. Also helping to prevent spoilage (Carvacho et al 2012).

Salicylic acid (from Latin Salix, willow tree) is a lipophilic mono hydroxybenzoic acid was a type of phenolic acid and beta hydroxyl acid. It has the formula $\mathrm{C}_{7} \mathrm{H}_{6} \mathrm{O}_{3}$ this colorless crystalline organic acid was widely used in organic synthesis and functions as a plant hormone. It was derived from the metabolism of salicin (Santiago et al 2011). The different crucifera species, flavonoids, phenylpropanoids and indole glucosinolates were induced by exogenous application of salicylic acid (Bennett and Wallsgrove, 1994), (Brader et al 2001), (Liang et al 2006) and (Mikkelsen et al 2003). In addition to serving as an important active metabolite of aspirin (acetylsalicylic acid), as acts in part as a prodrug to salicylic acid. It was probably best known for its use as a key ingredient in topical anti-acneproducts. The esters and salts of salicylic acid are known as salicylates (Baenas et al 2014).

Seed germination and production of sprouts is an old habit that was adopted thousands of year's age by the ancient Egyptians (Abdallah, 2008). 5000 years ago, Chinese nobles ate sprouted seeds for rejuvenation and healing. Research seems to be confirming that sprouts seed are the food of the future which was food of the past. It was well known that the consumption of plant based diet; mainly vegetables and whole grains are recommended as one of the ways to lower the risk of human diseases (Cadenas and Packer, 2002 and Li, Y. and Zhang, T. 2013).

Sprouts is a valuable but still under-appreciated dietary supplement which may be considered functional food and to meet consumer demands as well .Sprouting grains for human consumption have been used for centuries in Asian and Egypt to improve food value (Resh, 2001 and Abdallh, 2008) and (Maetinez-Villauenga et al 2008). This improvement was usually a result of breakdown of complex macromolecules such as proteins and starch into smaller and more digestible molecules, sprouts were lowering the amounts of antnutritional factors and some compounds with antioxidant effect increase Consumption of foods containing antioxidant may prevent some diseases. (Frias et al 2002 and Vidal-Valverde et al 2002 and Zikovie et al 2007).

The synthesis and accumulation of secondary metabolites, including phenolic compounds, forms part of the defense response of plants against the attack of pathogens, and it is activated by the presence of specific compounds or 'elicitors' in the surroundings of the plant. An elicitor is an organic or inorganic compound, or ion, that is released from fungi, bacteria, viruses or produced by the plant due to the attack of herbivores or pathogens. Elicitors trigger cascades of physiological responses that affect plant morphology and result in the synthesis and accumulation of phenolic compounds (Carvacho et al 2012 and Hooper \& Cassidy, 2006).

The aims of the present research were to evaluate effect of chitosan and salicylic acid as exogenous elicitors on broccoli seed germination and sprout characters chemical composition of broccoli sprout at 3,5 and 7 days.

\section{MATERIALS AND METHODS}

This study was carried out in Horticulture Department, Faculty of Agriculture, Ain Shams University and the Regional Center for Food and Feed (RCFF), Agriculture Research Center (ARC), Egypt during 2016 - 2017.

\section{Seed material and sprouting methods}

Seeds of Broccoli (Tiburon F1) were obtained from Agriculture Research center (ARC), Cairo. The seeds were rinsed in deionized water, immersed in $2 \mathrm{gl}^{-1}$ sodium hypochlorite for 20 minutes and drained. The seeds were weighed seeds $(4 \mathrm{~g})$ and tap water $(300 \mathrm{ml})$ was placed in a $0.7 \mathrm{~L}$ capacity glass jar (household version) which was then covered with cheese cloth secured by a rubber band. The jar was stored in dark for $12 \mathrm{hr}$ to allow seeds to soak at room temperature. After which soaking water was discarded and the seeds were rinsed with water in the jar (approximately 1.0 min). The rinse water was discarded; the jar was inverted at a $45^{\circ}$ angle and stored at room temperature in light for $12 \mathrm{hr}$ method as reported by Abdallah (2008). The rinse-store procedure was 

biochemical constituents of broccoli seed sprouts

repeated days until 3, 5, 7 days. Cumulative time had been completed (harvest time) Using tap water, chitosan at 25, 50,100 ppm and salicylic acid at $65,130,260 \mathrm{ppm}$ for seed soaking sprouting.

\section{Sprout characters}

At sprout harvest time also samples of sprouts were collected for measuring sprout characters (10 sprout length, hypocotyl length and radical length $(\mathrm{cm})$ and sprouts fresh and dry weight $(\mathrm{g})$. Broccoli sprouts harvested after 3 day from seed soaking. then harvested sprouts dried using air draft oven at $65^{\circ} \mathrm{C}$ then grounded into powder for chemical analysis.

\section{Chemical composition investigation of Broccoli}

All chemical composition analysis was carried out in the regional center for food and feed (RCFF), Agriculture Research Center (ARC).

\section{Proximate analysis}

Crude moisture, protein, ash, Fiber content broccoli seed sprouts are determined according to AOAC 2000.

\section{Minerals}

Calcium (Ca) and Potassium (K) were analyzed absorption spectrophotometry 3300 Perken Elmer according to the methods described in the AOAC 2000.

\section{Total phenol}

The total phenolic compounds of Broccoli seed sprouts were extracted with reaction mixture contained $200 \mu \mathrm{L}$ of a diluted thyme extract, $800 \mu \mathrm{L}$ of freshly prepared and diluted Folin-Ciocalteu reagent and $2 \mathrm{~mL}$ of $7.5 \%$ sodium carbonate ( $\mathrm{Na} 2$ $\mathrm{CO}_{3}$ ). The final mixture was diluted to a final volume of $7 \mathrm{~mL}$ with deionized water and the samples were incubated at room temperature for $72 \mathrm{~h}$ in the dark. The suspension was centrifuged by latching 3 times at room temperature and the supernatant was collected. In the next step, the absorbances of the solutions were measured at $765 \mathrm{~nm}$. Phenolic compounds were determined using Total Phenols method according to the (AOAC method 2005).

\section{Statistical analysis}

Statistical analysis was employed for each measured trait by analysis of variance (ANOVA) using completely randomized design and the mean were differentiated by significantly $(P \leq 0.05)$ according to (SAS, 2013).

\section{RESULTS AND DISCUSSION}

\section{Sprout length}

Data presented in Table (1) indicated that application of salicylic acid at 260 ppm was significantly at $(P \leq 0.05)$, while the chitosan 25 ppm content were found a progressive decrease $(P \leq 0.05)$ sprout length of broccoli at 3,5 and 7 days old compared with other exogenous elicitors treatments in the two seasons (2016 and 2017). Similar results were also obtained in broccoli sprouts, but only after 5 days of treatment (Zhang et al 2007). This results may be attributed that exogenous application of selected elicitors can stimulate the biosynthesis of secondary metabolites, leading to accumulation of phenolic and flavonoids with antioxidant activity and improving the phytochemical and nutritional value of sprouts.

\section{Hypocotyl length}

Data presented in Table (2), indicated that application of salicylic acid at $260 \mathrm{ppm}$ was significantly at $(P \leq 0.05)$, while the chitosan 25 ppm content were found a progressive decrease $(P \leq 0.05)$ Hypocotyl length $(\mathrm{cm})$ of broccoli at 3,5 and 7 days old compared with other exogenous elicitors treatments in the two season (2016 and 2017). These results were in concordance with those of (Goni et al 2013). The salicylic acid (SA) in 3 days old sprouts did not cause increased levels of broccoli sprouts; however salicylic acid (SA) concentrations during 5 days of treatment and all the solutions tested in 7 days old broccoli sprouts, significantly increased (Pérez-Balibrea et al 2011). 
Table 1. Effect of chitosan and salicylic acid elicitors on sprout length at 3,5 and 7days old- Broccoli seed sprouts in the two seasons (2016 and 2017)

\begin{tabular}{|l|c|c|c|c|c|c|}
\hline \multirow{2}{*}{\multicolumn{1}{|c|}{ Treatment }} & \multicolumn{2}{c|}{ 3 days } & \multicolumn{2}{c|}{ 5 days } & \multicolumn{2}{c|}{ 7 days } \\
\cline { 2 - 7 } & $\mathbf{2 0 1 6}$ & $\mathbf{2 0 1 7}$ & $\mathbf{2 0 1 6}$ & $\mathbf{2 0 1 7}$ & $\mathbf{2 0 1 6}$ & $\mathbf{2 0 1 7}$ \\
\hline Control (Tap Water) & $5.28 \mathrm{~d}$ & $5.20 \mathrm{~d}$ & $9.32 \mathrm{a}$ & $9.24 \mathrm{a}$ & $11.24 \mathrm{~b}$ & $11.26 \mathrm{ab}$ \\
Chitosan $25 \mathrm{ppm}$ & $5.00 \mathrm{e}$ & $4.93 \mathrm{e}$ & $8.94 \mathrm{~b}$ & $8.84 \mathrm{~b}$ & $10.87 \mathrm{~cd}$ & $10.84 \mathrm{c}$ \\
Chitosan 50 ppm & $4.88 \mathrm{f}$ & $4.82 \mathrm{f}$ & $8.27 \mathrm{c}$ & $8.22 \mathrm{c}$ & $10.82 \mathrm{c}$ & $10.69 \mathrm{c}$ \\
Chitosan 100 ppm & $4.44 \mathrm{~g}$ & $4.43 \mathrm{~g}$ & $7.46 \mathrm{~d}$ & $7.36 \mathrm{~d}$ & $10.49 \mathrm{e}$ & $10.46 \mathrm{~d}$ \\
salicylic acid 65 ppm & $5.48 \mathrm{c}$ & $5.40 \mathrm{c}$ & $7.43 \mathrm{~d}$ & $7.34 \mathrm{~d}$ & $10.95 \mathrm{c}$ & $10.85 \mathrm{c}$ \\
salicylic acid 130 ppm & $5.85 \mathrm{~b}$ & $5.83 \mathrm{~b}$ & $8.33 \mathrm{c}$ & $8.23 \mathrm{c}$ & $11.20 \mathrm{~b}$ & $11.12 \mathrm{~b}$ \\
salicylic acid 260 ppm & $6.23 \mathrm{a}$ & $6.22 \mathrm{a}$ & $9.34 \mathrm{a}$ & $9.26 \mathrm{a}$ & $11.48 \mathrm{a}$ & $11.42 \mathrm{a}$ \\
\hline
\end{tabular}

Mean Within a column for statistical with no common superscripts are significantly different $(P<0.05)$

Table 2. Effect of chitosan and salicylic acid elicitor on sprout hypocotyl length (cm) at 3, 5 and 7days old- Broccoli seed sprouts in two seasons (2016 - 2017)

\begin{tabular}{|l|c|c|c|c|c|c|}
\hline \multirow{2}{*}{\multicolumn{1}{|c|}{ Treatment }} & \multicolumn{2}{c|}{ 3 days } & \multicolumn{2}{c|}{ 5 days } & \multicolumn{2}{c|}{ 7 days } \\
\cline { 2 - 7 } & $\mathbf{2 0 1 6}$ & $\mathbf{2 0 1 7}$ & $\mathbf{2 0 1 6}$ & $\mathbf{2 0 1 7}$ & $\mathbf{2 0 1 6}$ & $\mathbf{2 0 1 7}$ \\
\hline Control (Tap Water) & $3.35 \mathrm{~b}$ & $3.25 \mathrm{~b}$ & $4.31 \mathrm{~b}$ & $4.24 \mathrm{a}$ & $7.04 \mathrm{c}$ & $7.05 \mathrm{c}$ \\
Chitosan 25 ppm & $3.13 \mathrm{c}$ & $3.10 \mathrm{c}$ & $3.51 \mathrm{~d}$ & $3.45 \mathrm{~b}$ & $7.11 \mathrm{c}$ & $7.07 \mathrm{c}$ \\
Chitosan 50 ppm & $2.92 \mathrm{~d}$ & $2.85 \mathrm{~d}$ & $3.46 \mathrm{~d}$ & $3.43 \mathrm{~b}$ & $6.74 \mathrm{~d}$ & $6.68 \mathrm{~d}$ \\
Chitosan 100 ppm & $2.37 \mathrm{e}$ & $2.41 \mathrm{e}$ & $3.65 \mathrm{c}$ & $3.58 \mathrm{~b}$ & $6.57 \mathrm{e}$ & $6.56 \mathrm{~d}$ \\
salicylic acid 65 ppm & $2.93 \mathrm{~d}$ & $2.91 \mathrm{~d}$ & $4.41 \mathrm{a}$ & $4.28 \mathrm{a}$ & $7.04 \mathrm{c}$ & $7.06 \mathrm{c}$ \\
salicylic acid 130 ppm & $3.38 \mathrm{~b}$ & $3.31 \mathrm{~b}$ & $4.41 \mathrm{a}$ & $4.36 \mathrm{a}$ & $7.44 \mathrm{~b}$ & $7.36 \mathrm{~b}$ \\
salicylic acid 260 ppm & $3.88 \mathrm{a}$ & $3.83 \mathrm{a}$ & $4.41 \mathrm{a}$ & $4.36 \mathrm{a}$ & $7.65 \mathrm{a}$ & $7.74 \mathrm{a}$ \\
\hline
\end{tabular}

Mean Within a column for statistical with no common superscripts are significantly different $(P<0.05)$

\section{Radical length}

Data presented in Table (3), indicated that application of salicylic acid at $65 \mathrm{ppm}$ was significantly at $(P \leq 0.05)$, while the chitosan 100 ppm content were found a progressive decrease $(P \leq 0.05)$ radical length $(\mathrm{cm})$ of broccoli at 3,5 and 7 days old compared with other exogenous elicitors treatments in the two season (2016 and 2017). But the longer the age, the reduced germination. Similar results on the reduction effect of sprout radical length were reported by (Ghoulam and Fares, 2001 and Ibrahim, 2010).

\section{Fresh weight}

Data presented in Table (4), indicated that application of salicylic acid at $260 \mathrm{ppm}$ was significantly at $(P \leq 0.05)$, while the chitosan 25 ppm content were found a progressive decrease $(P \leq 0.05)$ sprouts fresh weight $(\mathrm{g})$ of broccoli at 3, 5 and 7 days old compared with other exogenous elicitors treatments in the two season (2016 and 2017). The previous results are similar to those reported by (Fernandez-Orozco et al 2008, Krumbein et al 2010 and Poulev et al 2003).

\section{Dry weight}

Data presented in Table (5), indicated that application of salicylic acid at 260 ppm was significantly at $(P \leq 0.05)$, while the chitosan $100 \mathrm{ppm}$ content were found a progressive decrease $(P \leq$ $0.05)$ sprouts dry seeds ( $\mathrm{g} / 100 \mathrm{~g} \mathrm{DW})$. of broccoli at 3,5 and 7 days old compared with other exogenous elicitors treatments in the two season (2016 and 2017). Reduction of dry sprout weights relatively depended on sprout length, are similar to those reported by (Ghoulam and Fares, 2001). 

biochemical constituents of broccoli seed sprouts

Table 3. Effect of chitosan and salicylic acid elicitor on sprout radical length $(\mathrm{cm})$ at 3, 5 and 7 days old- Broccoli seed sprouts in the two seasons

\begin{tabular}{|l|c|c|c|c|c|c|}
\hline \multirow{2}{*}{ Treatment } & \multicolumn{2}{|c|}{ 3 days } & \multicolumn{2}{c|}{ 5 days } & \multicolumn{2}{c|}{$\mathbf{7}$ days } \\
\cline { 2 - 7 } & $\mathbf{2 0 1 6}$ & $\mathbf{2 0 1 7}$ & $\mathbf{2 0 1 6}$ & $\mathbf{2 0 1 7}$ & $\mathbf{2 0 1 6}$ & $\mathbf{2 0 1 7}$ \\
\hline Control (Tap Water) & $1.94 \mathrm{bc}$ & $1.96 \mathrm{bc}$ & $5.04 \mathrm{~b}$ & $4.98 \mathrm{~b}$ & $3.88 \mathrm{~b}$ & $3.91 \mathrm{ab}$ \\
Chitosan 25 ppm & $1.84 \mathrm{c}$ & $1.86 \mathrm{c}$ & $3.32 \mathrm{e}$ & $3.25 \mathrm{~d}$ & $3.83 \mathrm{~b}$ & $3.82 \mathrm{~b}$ \\
Chitosan 50 ppm & $1.95 \mathrm{C}$ & $1.95 \mathrm{bc}$ & $4.96 \mathrm{~b}$ & $4.82 \mathrm{~b}$ & $3.86 \mathrm{~b}$ & $3.91 \mathrm{ab}$ \\
Chitosan 100 ppm & $2.07 \mathrm{~b}$ & $2.02 \mathrm{~b}$ & $3.94 \mathrm{~d}$ & $3.85 \mathrm{c}$ & $3.95 \mathrm{~b}$ & $3.94 \mathrm{ab}$ \\
salicylic acid 65 ppm & $2.57 \mathrm{a}$ & $2.48 \mathrm{a}$ & $5.39 \mathrm{a}$ & $5.40 \mathrm{a}$ & $4.43 \mathrm{a}$ & $4.11 \mathrm{a}$ \\
salicylic acid 130 ppm & $2.55 \mathrm{a}$ & $2.53 \mathrm{a}$ & $4.06 \mathrm{C}$ & $4.00 \mathrm{c}$ & $3.83 \mathrm{~b}$ & $3.85 \mathrm{~b}$ \\
salicylic acid 260 ppm & $2.61 \mathrm{a}$ & $2.62 \mathrm{a}$ & $4.95 \mathrm{~b}$ & $4.99 \mathrm{~b}$ & $3.89 \mathrm{~b}$ & $3.90 \mathrm{ab}$ \\
\hline
\end{tabular}

Mean Within a column for statistical with no common superscripts are significantly different $(P<0.05)$

Table 4. Effect of chitosan and salicylic acid elicitor on sprouts Fresh Weight (g) at 3,5 and 7days old- Broccoli seed sprouts in the two seasons $(2016-2017)$

\begin{tabular}{|l|c|c|c|c|c|c|}
\hline \multirow{2}{*}{ Treatment } & \multicolumn{2}{|c|}{3 days } & \multicolumn{2}{c|}{5 days } & \multicolumn{2}{c|}{$\mathbf{7}$ days } \\
\cline { 2 - 7 } & $\mathbf{2 0 1 6}$ & $\mathbf{2 0 1 7}$ & $\mathbf{2 0 1 6}$ & $\mathbf{2 0 1 7}$ & $\mathbf{2 0 1 6}$ & $\mathbf{2 0 1 7}$ \\
\hline Control (Tap Water) & $25.23 \mathrm{~b}$ & $25.53 \mathrm{~b}$ & $39.26 \mathrm{a}$ & $39.50 \mathrm{a}$ & $52.36 \mathrm{~b}$ & $52.43 \mathrm{~b}$ \\
Chitosan 25 ppm & $24.53 \mathrm{c}$ & $24.50 \mathrm{C}$ & $37.50 \mathrm{c}$ & $37.23 \mathrm{~d}$ & $53.56 \mathrm{a}$ & $52.90 \mathrm{~b}$ \\
Chitosan 50 ppm & $23.83 \mathrm{~d}$ & $24.00 \mathrm{~d}$ & $36.45 \mathrm{~d}$ & $36.70 \mathrm{e}$ & $50.46 \mathrm{de}$ & $50.66 \mathrm{de}$ \\
Chitosan 100 ppm & $23.17 \mathrm{e}$ & $23.16 \mathrm{f}$ & $36.31 \mathrm{~d}$ & $36.10 \mathrm{f}$ & $50.37 \mathrm{e}$ & $50.23 \mathrm{e}$ \\
salicylic acid 65 ppm & $23.45 \mathrm{de}$ & $23.56 \mathrm{e}$ & $38.51 \mathrm{~b}$ & $38.50 \mathrm{c}$ & $50.84 \mathrm{~d}$ & $51.10 \mathrm{~cd}$ \\
salicylic acid 130 ppm & $25.27 \mathrm{~b}$ & $25.70 \mathrm{~b}$ & $39.05 \mathrm{a}$ & $38.80 \mathrm{bc}$ & $51.60 \mathrm{c}$ & $51.56 \mathrm{c}$ \\
salicylic acid 260 ppm & $26.38 \mathrm{a}$ & $26.50 \mathrm{a}$ & $39.35 \mathrm{a}$ & $39.44 \mathrm{a}$ & $53.31 \mathrm{a}$ & $53.46 \mathrm{a}$ \\
\hline
\end{tabular}

Mean Within a column for statistical with no common superscripts are significantly different $(P<0.05)$

Table 5. Effect of chitosan and salicylic acid elicitor on sprouts dry weight (g). at 3,5 and 7days oldBroccoli seed sprouts in the two seasons $(2016-2017)$

\begin{tabular}{|l|c|c|c|c|c|c|}
\hline \multirow{2}{*}{ Treatment } & \multicolumn{2}{c|}{ 3 days } & \multicolumn{2}{c|}{ 5 days } & \multicolumn{2}{c|}{ 7 days } \\
\cline { 2 - 7 } & $\mathbf{2 0 1 6}$ & $\mathbf{2 0 1 7}$ & $\mathbf{2 0 1 6}$ & $\mathbf{2 0 1 7}$ & $\mathbf{2 0 1 6}$ & $\mathbf{2 0 1 7}$ \\
\hline Control (Tap Water) & $2.63 \mathrm{c}$ & $2.66 \mathrm{~d}$ & $2.44 \mathrm{c}$ & $2.38 \mathrm{~d}$ & $2.33 \mathrm{~b}$ & $2.32 \mathrm{c}$ \\
Chitosan 25 ppm & $2.83 \mathrm{a}$ & $2.85 \mathrm{a}$ & $2.68 \mathrm{a}$ & $2.63 \mathrm{a}$ & $2.44 \mathrm{a}$ & $2.50 \mathrm{a}$ \\
Chitosan 50 ppm & $2.72 \mathrm{~b}$ & $2.76 \mathrm{bc}$ & $2.56 \mathrm{~b}$ & $2.52 \mathrm{~b}$ & $2.33 \mathrm{~b}$ & $2.29 \mathrm{~cd}$ \\
Chitosan 100 ppm & $2.67 \mathrm{c}$ & $2.65 \mathrm{~d}$ & $2.45 \mathrm{c}$ & $2.44 \mathrm{c}$ & $2.26 \mathrm{c}$ & $2.24 \mathrm{~d}$ \\
salicylic acid 65 ppm & $2.76 \mathrm{~b}$ & $2.74 \mathrm{c}$ & $2.25 \mathrm{e}$ & $2.22 \mathrm{f}$ & $2.24 \mathrm{c}$ & $2.24 \mathrm{~d}$ \\
salicylic acid 130 ppm & $2.73 \mathrm{~b}$ & $2.78 \mathrm{~b}$ & $2.28 \mathrm{e}$ & $2.24 \mathrm{f}$ & $2.33 \mathrm{~b}$ & $2.27 \mathrm{~d}$ \\
salicylic acid 260 ppm & $2.83 \mathrm{a}$ & $2.85 \mathrm{a}$ & $2.35 \mathrm{~d}$ & $2.29 \mathrm{e}$ & $2.41 \mathrm{a}$ & $2.41 \mathrm{~b}$ \\
\hline
\end{tabular}

Mean Within a column for statistical with no common superscripts are significantly different $(P<0.05)$

\section{Proximate composition}

The proximate composition of Broccoli seed sprouts using tap, chitosan and salicylic acid are presented in Table (6). Data showed using tap water (control), chitosan and salicylic acid increased moister, protein, ash and fiber value as compared with dry broccoli seed sprouts, could be due to a decreased in dry matter through respiration of young sprouts, due to here were no nitrogen source added externally to the water and chitosan and salicylic acid used for irrigation during sprouts. The chemical composition shows statistically significant differences $(P \leq 0.05)$ between the samples according to the germination time. 
Moisture contents of sprouts were significantly $(p<0.05)$ influenced by sprouting at Three days old. The mean value of moisture content ranged from $8.20 \%$ to $9.63 \%$ of dry sprouts from three days of germination. This moisture percent increase was therefore not a likely true increase (Chavan and Kadam, 1989 and Abdallah, 2008) and Dung et al (2010) the increment of moister content in sprouts in a dry weight basis as compared with dry seeds state. The original dry weight of the seeds decreased during sprouting process. The decrement in dry weight may be due to leaching of materials and oxidations of substances from the seeds during sprouting as reported by (Chavan and Kadam, 1989).

On the other hand, protein recorded higher content in both seasons with lower moisture content for all treatments. Protein content in broccoli sprout recorded $33.40 \%$ and $33.73 \%$ respectively with broccoli seed sprouting using chitosan at 100 ppm (Table 6). Also the protein content of sprouted broccoli was higher than that of whole dry seeds broccoli. This observation was greed with other scientific findings that sprouting improved protein content (Abdallah, 2008, Fasasi, 2009 and Ibrahim, 2017). Moreover (Abd El-Azim, et al 2019) reported that several enzymes were activated during germination process which produced some non-protein nitrogen substances, such as nucleic acid which can caused protein level to be increased.

Broccoli sprouts had lower increase of ash $11.63 \%$ and $11.80 \%$ on chitosan at $100 \mathrm{ppm}$ on seeds weight basis, respectively. This results similar reported by Aly, Tahany (2015).

Total fiber content increased as a result of sprouting of 3 days old etiolated in broccoli which reached in broccoli sprouts (11.43\% and $11.67 \%$ ) in chitosan at $100 \mathrm{ppm}$ on a dry weight basis (Table 6). Similar results reported by (El-Mahdy and El-Sebaiy, 1983), showed an increase in fiber of fenugreek seeds after germination (from $6.3 \%$ in seeds to $9.5 \%$ in sprouts).

Table 6. Effect of chitosan and salicylic acid content on evaluation the proximate composition of Broccoli seed sprouts ( 3 days old) in the two seasons (2016 and 2017)

\begin{tabular}{|l|c|c|c|c|c|c|c|c|}
\hline \multirow{2}{*}{\multicolumn{1}{c|}{ Treatment }} & \multicolumn{2}{|c|}{ Moisture \% } & \multicolumn{2}{c|}{ Protein \% } & \multicolumn{2}{c|}{ Ash \% } & \multicolumn{2}{c|}{ Fiber \% } \\
\cline { 2 - 9 } & $\mathbf{2 0 1 6}$ & $\mathbf{2 0 1 7}$ & $\mathbf{2 0 1 6}$ & $\mathbf{2 0 1 7}$ & $\mathbf{2 0 1 6}$ & $\mathbf{2 0 1 7}$ & $\mathbf{2 0 1 6}$ & $\mathbf{2 0 1 7}$ \\
\hline Control(Tap Water) & $8.3 \mathrm{~b}$ & $8.56 \mathrm{~b}$ & $32.33 \mathrm{c}$ & $32.40 \mathrm{~b}$ & $11.13 \mathrm{~cd}$ & $11.56 \mathrm{ab}$ & $11.36 \mathrm{a}$ & $11.33 \mathrm{a}$ \\
Chitosan 25 ppm & $8.53 \mathrm{~b}$ & $8.66 \mathrm{~b}$ & $32.73 \mathrm{~b}$ & $32.40 \mathrm{~b}$ & $11.36 \mathrm{bc}$ & $11.65 \mathrm{ab}$ & $11.36 \mathrm{a}$ & $11.63 \mathrm{a}$ \\
Chitosan 50 ppm & $8.20 \mathrm{~b}$ & $8.50 \mathrm{~b}$ & $32.3 \mathrm{c}$ & $32.36 \mathrm{~b}$ & $11.23 \mathrm{~cd}$ & $11.33 \mathrm{~b}$ & $11.23 \mathrm{a}$ & $11.36 \mathrm{a}$ \\
Chitosan 100 ppm & $9.16 \mathrm{a}$ & $9.63 \mathrm{a}$ & $33.40 \mathrm{a}$ & $33.73 \mathrm{a}$ & $11.63 \mathrm{a}$ & $11.80 \mathrm{a}$ & $11.43 \mathrm{a}$ & $11.67 \mathrm{a}$ \\
salicylic acid 65ppm & $9.16 \mathrm{a}$ & $9.53 \mathrm{a}$ & $33.63 \mathrm{a}$ & $33.40 \mathrm{a}$ & $10.86 \mathrm{c}$ & $11.63 \mathrm{a}$ & $10.76 \mathrm{~b}$ & $10.46 \mathrm{~b}$ \\
salicylic acid 130ppm & $9.26 \mathrm{a}$ & $9.43 \mathrm{a}$ & $32.33 \mathrm{c}$ & $32.53 \mathrm{~b}$ & $11.03 \mathrm{de}$ & $11.33 \mathrm{~b}$ & $11.16 \mathrm{a}$ & $11.56 \mathrm{a}$ \\
salicylic acid 260ppm & $9.30 \mathrm{a}$ & $9.60 \mathrm{a}$ & $32.23 \mathrm{c}$ & $32.53 \mathrm{~b}$ & $11.7 \mathrm{ab}$ & $11.50 \mathrm{ab}$ & $11.30 \mathrm{a}$ & $11.56 \mathrm{a}$ \\
\hline
\end{tabular}

Mean Within a column for statistical with no common superscripts are significantly different $(\mathrm{P}<0.05)$

\section{Mineral and Total phenols of Broccoli seed sprouts}

The mineral composition of broccoli sprout was shown in Table (7). The mineral composition showed that potassium (K) had the highest value in the broccoli seed sprouting using chitosan at $100 \mathrm{ppm}$ which recorded the highest $\mathrm{Ca}$ and $\mathrm{K}$ values for both broccoli (from 336.50 and 196.43 ppm). However the high intake of potassium has been reported to protect against increasing blood pressure and other cardiovascular risk. Broccoli sprout are rich in vit. B6, c, E and k, folic acid, phosphorus, dietary fiber, potassium $(\mathrm{K})$ and $\mathrm{Mg}$. which help prevention of cancer and regenerate the immune system (Ibrahim et al 2002), (Cappuccio and McGregor, 1991 and LangFord, 1983).

Data regarding the Total phenols content of Chitosan 100 ppm and sprouted broccoli as a function of sprouting time is depicted in Table (7). Total phenols contents of sprouts were significantly $(p<$ 0.05 ) influenced by sprouting at 3 days old. The mean value of Total phenols content in sprouted seeds was $66.40 \mathrm{mg} / 100 \mathrm{~g}$ which increased to $66.51 \mathrm{mg} / 100 \mathrm{~g}$ in sprouted seeds after 3days old sprouting time. These results agree with those reported that Japanese broccoli sprout had higher flavonoids (Takaya et al 2004). 
Table 7. Effect of chitosan and salicylic acid content on evaluation of mineral and total phenols of Broccoli seed sprouts ( 3 days old) in the two seasons (2016 and 2017)

\begin{tabular}{|c|c|c|c|c|c|c|}
\hline \multirow{3}{*}{ Treatment } & \multicolumn{4}{|c|}{ Mineral (ppm) } & \multirow{2}{*}{\multicolumn{2}{|c|}{$\begin{array}{c}\text { Total Phenols } \\
\mathrm{mg} / 100 \mathrm{~g}\end{array}$}} \\
\hline & \multicolumn{2}{|c|}{$\mathrm{Ca}$} & \multicolumn{2}{|c|}{$\mathrm{K}$} & & \\
\hline & 2016 & 2017 & 2016 & 2017 & 2016 & 2017 \\
\hline Control(Tap Water) & $304.40 \mathrm{~d}$ & $304.56 \mathrm{~d}$ & $160.50 \mathrm{~d}$ & $160.83 \mathrm{~d}$ & $61.80 \mathrm{~d}$ & $61.76 \mathrm{~d}$ \\
\hline Chitosan 25 ppm & $334.50 \mathrm{~b}$ & $334.63 \mathrm{~b}$ & $190.60 \mathrm{~b}$ & $190.80 \mathrm{~b}$ & $63.60 \mathrm{~b}$ & $63.33 \mathrm{bc}$ \\
\hline Chitosan 50 ppm & $334.36 \mathrm{bc}$ & $334.63 \mathrm{~b}$ & $189.06 \mathrm{c}$ & $189.36 \mathrm{c}$ & $63.73 \mathrm{~b}$ & $63.63 \mathrm{~b}$ \\
\hline Chitosan 100 ppm & $336.30 \mathrm{a}$ & $336.50 \mathrm{a}$ & $196.10 \mathrm{a}$ & $196.43 \mathrm{a}$ & $66.51 \mathrm{a}$ & $66.40 \mathrm{a}$ \\
\hline salicylic acid 65 ppm & $333.80 \mathrm{c}$ & $333.50 \mathrm{c}$ & $190.40 \mathrm{~b}$ & $190.60 \mathrm{~b}$ & $62.60 \mathrm{c}$ & $62.90 \mathrm{c}$ \\
\hline salicylic acid 130 ppm & $297.43 \mathrm{e}$ & $297.56 \mathrm{e}$ & $155.33 \mathrm{f}$ & $155.70 \mathrm{f}$ & $57.50 \mathrm{e}$ & $57.30 \mathrm{e}$ \\
\hline salicylic acid 260 ppm & $297.56 \mathrm{e}$ & $297.70 \mathrm{e}$ & $156.50 \mathrm{e}$ & $156.73 \mathrm{e}$ & $57.56 \mathrm{e}$ & $57.50 \mathrm{e}$ \\
\hline
\end{tabular}

Mean Within a column for statistical with no common superscripts are significantly different $(P<0.05)$

\section{REFERENCES}

Abdallah M.M.F. 2008. Seed sprouts, a pharaoh's heritage to improve food quality. Arab Universities J. of Agric. Sci. 16 (2), 469-478.

Abd El-Azim M.A. , Nashwa A.I. Abo El-Azam, Afaf O. Serage and Abdallah M.M.F. 2019. Sprouting using saline water on chemical composition, ant nutritional compounds and amino acid profile of chickpea and lentil seeds. Arab Univ. J. Agric. Sci., 26(2), 2239-2251.

A.O.A.C. 2005. Official Methods of Analysis the association of analytical chemists $18^{\text {th }} \mathrm{Ed}$., Washington, D.C.USA.

Baenas N., Cristina G.V. and Diego A.M. 2014. Elicitation: A Tool for Enriching the Bioactive Composition of Foods. Molecules. 19, 1354113563.

Bautista-Banos S., Hernández-Lauzardo A.N., Velázquez-del Valle M.G., Hernández-López M., Ait Barka E., Bosquez-Molina E. and Wilson C.L. 2006. Chitosan as a potential natural compound to control pre and postharvest diseases of horticultural commodities. Crop Prot. 25, 108-118.

Bennett R.N. and Wallsgrove R.M. 1994. Secondary metabolites in plant defence mechanisms. New Phytologist, 127(4), 617-633.

Brader G., Tas E. and Palva E.T. 2001. Jasmonate-dependent induction of indole glucosinolates in Arabidopsis by culture filtrates of the nonspecific pathogen Erwinia carotovora. Plant Physiology, 126(2), 849-860.

Cadenas E. and Packer L. 2002. Handbook of antioxidants. New York, Marcel Dekker. Capacities of ITCs. Environ. Mol. Mutagen. 50, 222237.

Cappuccio F.P. and McGregor G.A. 1991. Does potassium supplementation lower blood pressure A meta- analysis of published trials. J. Hypertens, 9, 465-473.

Carvacho H.B., Pérez C., Zúñiga G. and Mahn A. 2012. Effect of methyl jasmonate, sodium selenate and chitosan as exogenous elicitors on the phenolic compounds profile of Broccoli seed sprouts. Society of Chemical Industry. Food Chem., 10, 1016-1037.

Chavan J. and Kadam S.S. 1989. Nutritional importance of cereals by sprouting. Critical Rev Food Sci. Nutr. 28, 349-400.

Dung D.D., Goodwin I.R. and Nolan J.V. 2010. Nutrient content and in sacco digestability of barly grain and sprouted barley. J. Anim. and Vet. Advan. 9, 2485-2494.

El-Mahdy A.R. and El-Sebaiy L.A. 1983. Changes in carbohydrates of germinating fenugreek seeds (Trigonella foenum-graecum L.) J. Sci. Food and Agric., 34, 951-956.

Fasasi O.S. 2009. Proximate antinutritional factors and functional properties of processed pearl millet (P. ennisetumglaucum). J. Food Technol., 7(3), 92-97. 
Fernandez-Orozco R., Frias J., Zielinski H., Piskula M.K., Kozlowska H. and VidalValverde C. 2008. Kinetic study of the antioxidant compounds and antioxidant capacity during germination of Vigna radiata $\mathrm{cv}$. emmerald, Glycine max cv. jutro and Glycine max cv. merit. Food Chemistry, 111, 622-630.

Frias J., Fernandez-Orozco R., Zielinski H., PisKula M., Hozlowska H. and VidalValverde C. 2002. Effects of Germination on the content of vitamins $\mathrm{C}$ and $\mathrm{E}$ of lentils. Polish J. of Food and Nutrition Sci., 11/52 (S11), 76-78.

Ghoulam C. and Fares K. 2001. Effect of Salinity on seed Germination and Early Seeding Growth of Suger Beet Cultivars. AmericanEurasian J. of Sustainable Agric. 6(2), 120125.

Goni M.G., Moreira M.R., Viacava G.E. and Roura S.I. 2013. Optimization of chitosan treatments for managing microflora in lettuce seeds without affecting germination. Carbohydr. Polym. 92, 817-823.

Hooper L. and Cassidy A. 2006. A review of the health care potential of bioactive compounds. J. of the Sci. of Food and Agric., 86(12), 1805-1813.

Ibrahim E.M.R. 2010. Environmental and Nutritional Safe Production of Green Sprouts in House. M.Sc. Thesis, Dept. of Agric. Sci. Institute of Environmental Studies and Research, Fac. of Agric., Ain Shams Univ., Cairo, Egypt. 87 p.

Ibrahim E.M.R. 2017. Effect of sprouting using saline water on characters and chemical composition of some legumes and cereals seeds. Ph.D. Thesis, Dept. of Agric. Sci. Institute of Environmental Studies and Research, Fac. of Agric., Ain Shams Univ., Cairo, Egypt. 43 p.

Ibrahim S.S., Habiba R.A. Shatta A.A. and Embaby H.E. 2002. Effect of soaking germaintion, cooking and fermentation on anti-nutritional factors in cowpeas. Food/Nahrung, 46(2), 9295.

Jeffery E.H. and Araya M. 2009. Physiological effects of broccoli consumption. Phytochemistry Reviews, 8(1), 283-298.

Jinjun Gao, Xinxin Yu, Fengming Ma and Jing Li 2014. RNA-Seq Analysis of Transcriptome and Glucosinolate Metabolism in Seeds and Sprouts of Broccoli (Brassica oleracea var. italic). Published February 27, 485-497.
Krumbein A., Schonhof I., Smetanska I., Scheuner E.T., RühImann J. and Schreiner M. 2010. Improving levels of bioactive compounds in Brassica vegetables by crop management strategies. Acta Horticulturae, 856, 37-48.

Langford H.G. 1983. Dietary potassium and hypertension: epidemiologic data. Ann. Lnt. Med. 98(2), 770-772.

Lee Y.S., Kim Y.H. and Kim S.B. 2005. Changes in the respiration, growth, and vitamin $\mathrm{C}$ content of soybean sprouts in response to chitosan of different molecular weights. HortScience, 40(5), 1333-1335.

Li Y. and Zhang T. 2013. Targeting cancer stem cells with sulforaphane, a dietary component from broccoli and Broccoli seed sprouts. Future Oncol. 9, 1097- 1103.

Liang Y.S., Choi Y.H., Kim, H. K., Linthorst, H. J. M., and Verpoorte, R. 2006. Metabolomic analysis of methyl jasmonate treated Brassica rapa leaves by 2 - dimensional NMR spectroscopy. Phytochemistry, 67(22), 2503-2511.

Martinez-Villaluenga, C., J. Frias; P. Gulewiez; K. Gulewiez and C. Vidal-Valverde, 2008. Food safety evaluation of broccoli and radish sprouts. Food and Chemical Toxicology 46, 1635-1644.

Mikkelsen, M. D., Petersen, B. L., Glawischnig, E., Jensen, A. B., Andreasson, E., and Halkier, B. A, 2003. Modulation of CYP79 genes and glucosinolate profiles in Arabidopsis by defense signaling pathways. Plant Physiology, 131(1), 298-308.

No H.K., Lee K.S., Kim I.D., Park M.J., Kim S.D. and Meyers S.P. 2003. Chitosan treatment affects yield, ascorbic acid content, and hardness of soybean sprouts. J. Food Sci. 68, 680-685.

Peer D.J. and Leeson S. 1985. Nutrient content of hydroponically sprouted barley. Anim. Feed. Sci. Technol. 13, 191-202.

Pérez-Balibrea S., Moreno D.A. and GarcíaViguera C. 2011. Improving the phytochemical composition of broccoli sprouts by elicitation. Food Chem. 129, 35-44.

Poulev A., O'Neal J. M., Logendra S., Pouleva R.B., Timeva V. and Garvey A.S. 2003. Elicitation, a new window into plant chemodiversity and phytochemical drug discovery. J. of Medicinal Chemistry, 46(12), 2542-2547.

Resh H.M. 2001. Hydroponic Food Production, 6th ed Woodbridge press, Santa Barbara, CA., $567 \mathrm{p}$. 

biochemical constituents of broccoli seed sprouts

SAS 2013. Snedecor, G. W. and Cochran, W.G. Statistical Methods 7th Ed. lowa State University press. Ames, lowa, USA. 507 p.

Tahany A.A. Aly 2015. Biochemical studies of antidiabitec effect of some seed sprouts in adult male albino rats. Ph.D. Thesis Department of Biochemistry, Fac. of Agric., Cairo Univ., Giza, Egypt. 73 p.

Takaya Y., Kondo Y., Furukawa T. and Niwa M. 2003. Antioxidant Constituents of broccoli Sprout (Belstar), Brassica oleracea var. J. of Agric. and Food Chemistry, 51, 8061-8066.

Vidal-Valverde C., Frias J., Sierra I., Blazquez I., Lambein F. and Kuo Y. 2002. New functional legume foods by germination, effect on the nutritive value of beans, lentils and peas. European Food Rescarch and Technology, 215, 472-477.

Zhang H., Vasanthan T. and Wettasinghe $M$. 2007. Enrichment of tocopherols and phytosterols in canola oil during seed germination. J. Agric. Food Chem. 55, 355-359.

Zivkovie S., Devic M., Filipovie B., Giba Z. and Grubisic D. 2007. Effect of $\mathrm{NaCl}$ on seed germination in some Centaurium Hill. Species (Gentianaceae). Arch. Biol. Sci., 59(3), 227231. 


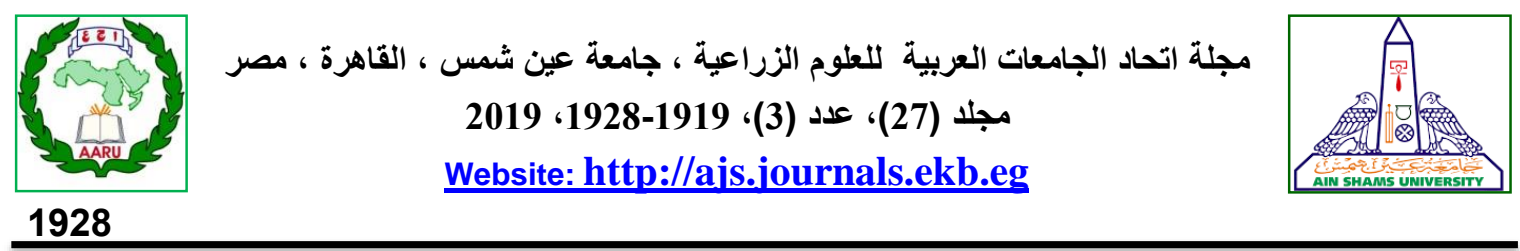

تأثير إستخدام بعض المستحثات علي صفات النمو والمركبات الكيموحيوية لنبت بذور البروكلي

[153]

رشا محسن بندق1" - أحمد أبو اليزيل2 - هاني جمال عبد الجواد2 - زينب محمد عبد الغني1 1

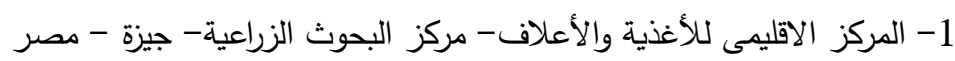

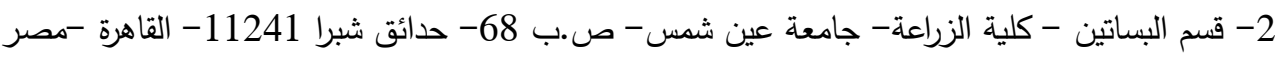

*Corresponding author: rashabondok@agr.asu.edu.eg

Received 23 June, 2019

Accepted 29 July, 2019

محتوي النبت من الرطوبة والبروتين والرماد والألياف

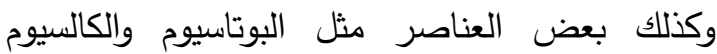

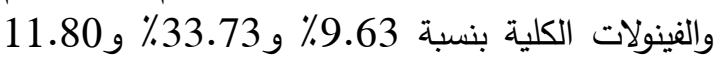

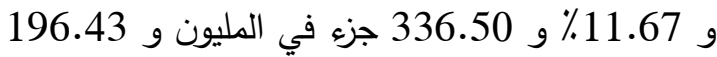

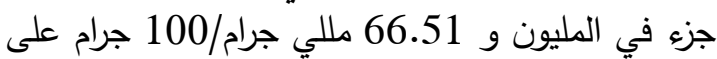
التوالي وذلك عند المعاملة بالثشيتوزان بتركيز 100 جزي

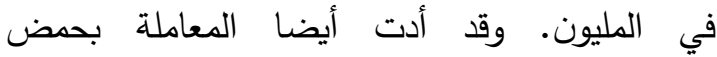
الساليسيليك بتركيز 65 جزء في المليون إلي حدوث إرتقاع في محتوي النبت من المركبات سابقه الذكر فرك

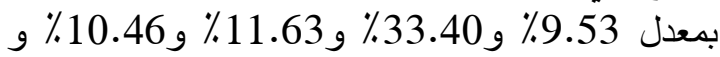

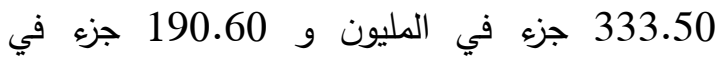

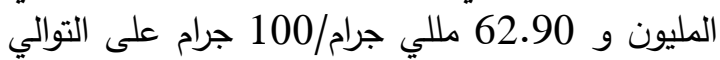
بالمقارنة (ماء الصنبور). ونخلص من تلك الدراسه

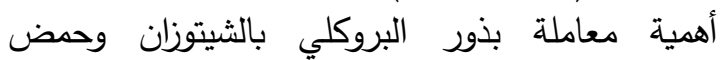
الساليسليك لتحسين الخواص الخضرية للنبت الناتج

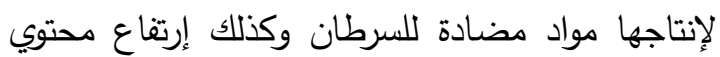

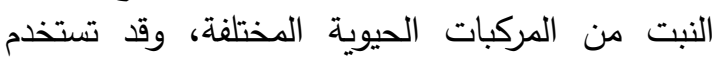
ايضا ما قبل حصاد المحاصيل لتحفيز الخلايا النباتية على انتاج المواد التى تساعدها على تلى تحمل الاجهاد التهاد

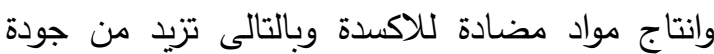

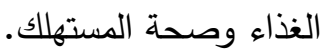

الكلمات الداله: نبت البذور، البروكلي، شيتوزان،

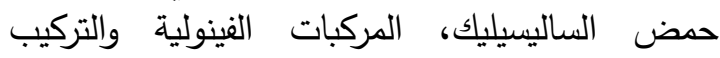
الكيميائي

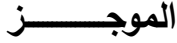

تهدف الدراسة إلي معرفه تأثير معاملة بذور

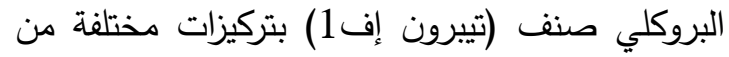
الثيتوزان وحمض الساليسيليك علي الصفات الخضرية الترية

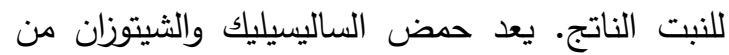

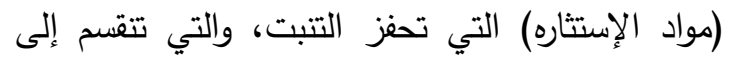

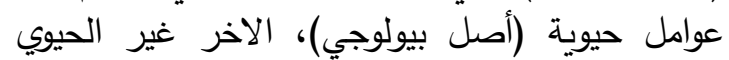

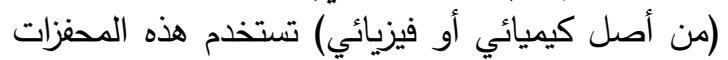

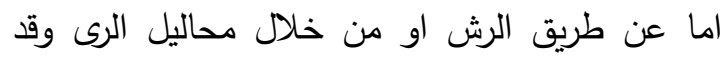
تستخدم اثناء نمو البذور او التتبيت. قد تم الانتهاء من الترن

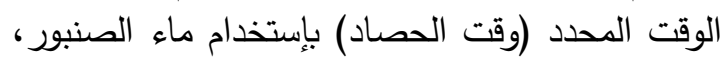

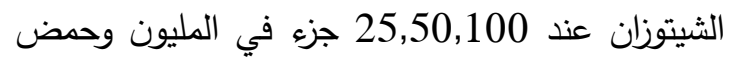

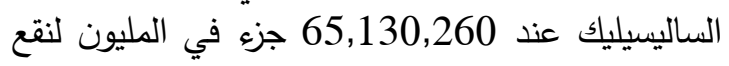
البذور وتنبيتها. ثم تم اختيار براعم قبل التجفيف

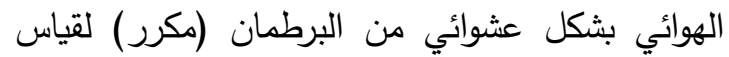

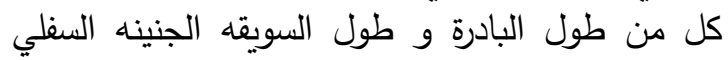
وطول الجذير وكذلك الوزن الطازج و الجاف للبادرات اليضا تم تجفيف عينات البروكلي تحت الطائ الاعمار المختلفة (3,5,7 أيام) باستخدام فرن التجفيف عندات

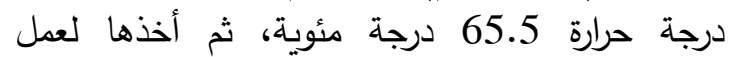
التحليلات الكيميائية في حين تم تحليل الفينولات الكلية

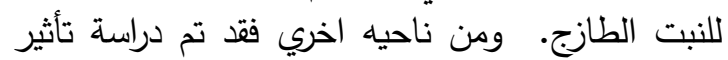
استخدام الثيتوزان وحمض الساليسيليك علي المركبات الحيوية لنبت البروكلي بعمر 3 أيام. وقد لوحظ أن الن الن الت 
